\title{
LEAF AND PETIOLE EXTRACT OF Centella asiatica ARE POTENTIAL FOR ANTIFERTILITY AND ANTIMICROBIAL MATERIAL
}

\author{
Susie Amilah, Sukarjati, Diaz P Rachmatin, Masruroh \\ Biology Study Program, Faculty of Science and Mathematics, PGRI Adi Buana University
}

\section{ABSTRACT}

\begin{abstract}
Ethanol extract of leaves and petiole of pegagan (Centella asiatica) is potential as antimicrobial and antifertility. This study was to investigate whether ethanol extracts of leaf and petiole of Centella asiatica has potential as an antimicrobial and can decrease sperm quality and spermatogenic cells of mice. This was a randomized controlled study using Centella asiatica plant from which we made ethanol extract. The extract of the leaves and petiole of Centella asiatica was subjected to antimicrobial test using the bacteria $S$. aureus, S. epidermidis, and A. aerogenes. Then the observation was done after a 24-hour-old bacterial cultures by measuring the diameter of the clear zone in mm. Thereafter, the extract was given to randomly grouped mice that were divided into two groups receiving the leaf extract in one group and the petiole exract in another for 35 days. On day 36 the mice were sacrificed for spermatozoa quality and testicular histology examination. Statistical analyses used in this study were ANOVA and LSD tests. There was inhibition zone difference between leaf and petiole $(p=0.000)$. Inhibition zone between bacteria S. epidermidis, $S$. aureus and A. aerogenes showed no difference $(p=0.198)$. Inter-dose inhibition zone showed difference $(p=0.000)$. Centella asiatica leaf extract showed inhibition zone better than that of Centella asiatica petiole extract. In spermatozoa quality test, there was effect of Centella asiatica leaf extract on sperm motility $(p<0.05)$, viability $(p<0.05)$, morphology $(p<0.05)$ and concentration $(p<0.05)$. No effect of pegagan petiole extract was found on sperm motility $(p<0.05)$, viability $(p<0.05)$, abnormal morphology $(p<0.05)$ and concentration $(p<0.05)$. Highest degradation of spermatozoa quality was obtained from Centella asiatica petiole extract at a concentration of 150 $\mathrm{mg} / \mathrm{kg} \mathrm{bw}$. Spermatogenic cell test results showed no effect of Centella asiatica leaf extract in decreasing spermatogonia $(p=0.000)$, spermatocytes $(p=0.000)$, and spermatids $(p=0.000)$ counts. No effect of pegagan petiole extract in decreasing the number of spermatogonia, spermatocytes and spermatids. The highest reduction spermatogenic cells of seminiferous tubules was obtained by Centella asiatica petiole extract in a concentration of $150 \mathrm{mg} / \mathrm{kg} \mathrm{bw}$. In conclusion: Centella asiatica leaf and petiole extract has antimicrobial potency as contraceptives.
\end{abstract}

Keywords: ethanol extract of Centella asiatica leaf and petiole; antimicrobials, quality of spermatozoa, spermatogonia, spermatocytes, spermatids

\section{ABSTRAK}

Ekstrak etanol daun dan tangkai daun pegagan (Centella asiatica) berpotensi sebagai antimikroba dan antifertilitas. Penelitian ini adalah untuk menyelidiki apakah ekstrak etanol daun dan tangkai daun dari Centella asiatica berpotensi sebagai antimikroba dan dapat menurunkan kualitas sperma dan sel spermatogenik mencit. Ini adalah penelitian terkontrol secara acak menggunakan tanaman Centella asiatica dari mana kami membuat ekstrak etanol. Ekstrak daun dan tangkai daun dari Centella asiatica menjadi sasaran uji antimikroba menggunakan bakteri S. aureus, S. epidermidis, dan A. aerogenes. Kemudian pengamatan dilakukan setelah kultur bakteri berumur 24 jam dengan mengukur diameter zona bening dalam mm. Setelah itu, ekstrak diberikan kepada mencit yang dikelompokkan secara acak yang dibagi menjadi dua kelompok yang menerima ekstrak daun dalam satu kelompok dan tangkai daun dikeluarkan dalam kelompok lain selama 35 hari. Pada hari ke-36 mencit dikorbankan untuk kualitas spermatozoa dan pemeriksaan histologi testis. Analisis statistik yang digunakan dalam penelitian ini adalah tes ANOVA dan LSD. Ada perbedaan zona hambat antara daun dan tangkai daun $(p=0,000)$. Zona penghambatan antara bakteri S. epidermidis, S. aureus dan A. aerogenes tidak menunjukkan perbedaan $(p=0,198)$. Zona penghambatan antar dosis menunjukkan perbedaan $(p=0,000)$. Ekstrak daun Centella asiatica menunjukkan zona penghambatan lebih baik daripada ekstrak petiole Centella asiatica. Dalam uji kualitas spermatozoa, terdapat pengaruh ekstrak daun Centella asiatica terhadap motilitas sperma $(p<0,05)$, viabilitas $(p<0,05)$, morfologi $(p<0,05)$ dan konsentrasi $(p<0,05)$. Tidak ada efek ekstrak petiole pegagan yang ditemukan pada motilitas sperma $(p<0,05)$, viabilitas $(p<0,05)$, morfologi abnormal $(p<0,05)$ dan konsentrasi $(p<0,05)$. Degradasi kualitas spermatozoa tertinggi diperoleh dari ekstrak Centella asiatica petiole pada konsentrasi $150 \mathrm{mg} / \mathrm{kg}$ bb. Hasil tes sel spermatogenik menunjukkan tidak ada efek dari ekstrak daun Centella asiatica dalam menurunkan spermatogonia $(p=0,000)$, spermatosit $(p=0,000)$, dan jumlah spermatid $(p=0,000)$. Tidak ada efek ekstrak petiole pegagan dalam mengurangi jumlah spermatogonia, spermatosit dan spermatid. Sel-sel spermatogenik reduksi tertinggi tubulus seminiferus diperoleh oleh ekstrak petiole Centella asiatica dalam konsentrasi $150 \mathrm{mg} / \mathrm{kg} \mathrm{bb}$. Sebagai simpulan, Ekstrak etanol daun dan tangkai daun pegagan (Centella asiatica) berpotensi sebagai alat kontrasepsi.

Kata kunci: ekstrak etanol daun dan tangkai Centella asiatica, antimikrobial, kualitas spermatozoa, spermatogonia, spermatosit, spermatid

Correspondence: Sukarjati, Biology Study Program, Faculty of Science and Mathematics, PGRI Adi Buana University, Surabaya, Indonesia. E-mail: sukarjati2016@gmail.com

pISSN:2355-8393 • eISSN: 2599-056x • doi: http://dx.doi.org/10.20473/fmi.v55i3.15498

- Fol Med Indones. 2019;55:188-197 • Received 31 May $2018 \bullet$ Accepted 11 Oct 2018

- Open access under CC-BY-NC-SA license • Available at https://e-journal.unair.ac.id/FMI/ 


\section{INTRODUCTION}

Male contraceptive is currently limited, making it necessary to develop ideal male contraceptive drug. One of the efforts to achieve such goal is to find alternative materials from natural resources. Plants are still a major source of new drugs and are a priority for study because of drugs from plant material has the advantage of low toxicity, easily available, inexpensive and side effects are relatively low. Indonesia is rich in medicinal plants, such as Pegagan (Centella asiatica L). The main chemical constituents of Centella asiatica are triterpenes saponisida namely Asiatic acid, Madaciatic acid (6-hydroxy Asiatic acid), Asiaticoside, Madecassoside; Madasiatic acid, betulinic acid, thankunic acid and isothankunic acid (Pan et al 2007) and treterpene. The others are brachmic acid, centellin, asiaticin, bayogenin, terminolic acid, Centella sapogenol A, Centella saponin $A-D$, ursolic acid, pomolic acid (Rumalla et al 2010). Flavonoid derivatives include quercetin, kaempferol, and myricetin patuletin (Subban et al 2008). The contents of polysaccharides that can be isolated are, for example, centellose (Wang et al 2004), cadinol poliacetelene eg, acetoxy centelinol, centellin, centellicin and asiaticin (Govindan et al 2007); sterols eg 11-oxoheneicosanilcyclhexane, sitosterol 3-O- $\square$-glucosida and castasterone (Sondhi et al 2010); and phenolic acid, including rosmarinic acid, ettacrynic acid, chlorogenic acid, and isochlorogenic acid (Suntornsuk \& Anurukvorakun 2005).

Centella asiatica have properties of anti-inflammatory, anti-ulcer, hepatoprotective, anticolvulsant, sedatives, antidiabetic, anti-viral, antibacterial, and antifungal. Besides, Centella asiatica is used as ingredients in traditional contraceptive in Bengal. Centella asiatica showed in vivo antifertility activity, antizygotic and causing early abortions. Different parts of the plant have the number and type of different active ingredients. Differences in the leaves and petiole of Centella asiatica as an antimicrobial and antifertility has not been investigated. This study aimed to investigate whether ethanol extracts of leaf and petiole of Centella asiatica has potential as an antimicrobial and can decrease sperm quality and spermatogenic cells of mice. The results of this study can be used to determine which extract of Centella asiatica, leaf or petiole, is more potential to be developed as a antimicrobial contraceptive material.

\section{MATERIALS AND METHODS}

This was a randomized controlled study. The plant used in this study was obtained from Centella asiatica taken from a village of Pacet Mojokerto in East Java province. From a total of $5 \mathrm{~kg}$ of Centella asiatica, the leaves and petiole were separated, then sorted and washed with running water. After that, they were dried without being exposed to the sun for 3 days at room temperature. Leaves and petiole were separately blended until became smooth. Powdered leaf and petiole of Centella asiatica was sifted in order to obtain a fine powder. Then leaf and petiole powder of Centella asiatica was extracted by maceration techniques. Each $100 \mathrm{~g}$ of the powder was dissolved in $1000 \mathrm{ml}$ of $70 \%$ ethanol for 3 days and stirred occasionally. The extraction was filtered using filter paper, then the extracted filtrate was concentrated by using a rotary evaporator at a temperature of 70 degrees $\mathrm{C}$. The extraction was heated in the oven with a temperature of 75 degrees $C$. The extract was dried, ready to be used for treatment.

Extracts of leaves and petiole were made in concentrations of $500,250,125,62.5 \mathrm{mg} / \mathrm{mL}$ (test solution). Furthermore blank paperdisk (diameter $6 \mathrm{~mm}$ ) was etched with $20 \mathrm{~mL}$ of test solution, and allowed to dry. S. aureus, S. epidermidis, and A. aerogenes were obtained from Regional Health Laboratory Surabaya. The bacteria were cultured on BHI medium and incubated for 24 hours. Bacterial cultures, which had only 24 hours, were centrifuged and the pellet obtained was added with PBS and homogenized by vortexing. Furthermore, the bacterial suspension was made turbidity at $\mathrm{OD}=0.1$ (bacterial count of about $10^{8}$ ) using a spectrophotometer. As much as $100 \mathrm{~mL}$ bacterial suspension was mixed with $20 \mathrm{ml}$ of nutrient agar media (in the warm), homogenized by vortexing, then poured into a petri dish, and left until the media became solidified. Paperdisk containing the test solution was then placed on the surface of the agar medium, and incubated at $37^{\circ} \mathrm{C}$ for 24 hours. Positive controls used ciprofloxacin 10 $\mathrm{mg} /$ disk and negative controls used paperdisk that has been poured with water. Observations were performed after a 24hour-old bacterial cultures by measuring the diameter (including paperdisk $6 \mathrm{~mm}$ ) of clear zone (inhibition zone) using a ruler in $\mathrm{mm}$ to test the effect of leaves and petiole extracts of Centella asiatica on the quality of spermatozoa and spermatogenic cells in mice.

Animals used were fertile mice of 2.5 months old weighing between 25-30 grams obtained from Pusvetma Surabaya. Before being treated, the mice were acclimatized at room temperature an average of $23-27^{\circ} \mathrm{C}$. This period lasted for 7 days for the mice to adapt to the environmental conditions that will be occupied during the experiment. The mice were

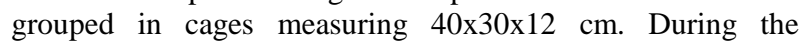
acclimatization the mice were given food and drink. Every day the cage was cleaned. The mice were grouped randomly. The mice were divided into 2 groups (group A and B), each group was divided into 3 sections (I, II and III). Group A was fed with extracts of Centella asiatica leaf and group B received the extract of Centella asiatica petiole. The dose of Centella asiatica leaf and petiole extract used in this study was 125 $\mathrm{mg} / \mathrm{kg}$ bw and $150 \mathrm{mg} / \mathrm{kg}$ bw and the control group was given water. Treatment of mice was given orally using a gavage once daily for 35 days. On day 36 mice were sacrificed, dissected, and the testicular epididymis was taken. Very carefully the testis and epididymis were separated and the epididymis was placed on a watch cup already containing sperm washing for observing sperm quality, while the testis was placed in the receptacle containing Bouin solution for producing histological preparations. 
Proximal part of caudal epididymis was very carefully treated by cutting the caudal epididymis which was pressed very gently until the liquid secretions of epididymal sperm was washed out into the suspension. Spermatozoa suspension was used for observation of the quality of spermatozoa which included concentration, motility and viability, and morphology. We calculated the number of motile sperm in \% using a microscope. Observations was made by staining viable sperm using eosin nigrosin. We calculated the number of viable and dead in \%. Viable spermatozoa were colorless while dead spermatozoa were red. Sperm concentration was calculated using Neuber Haemocytometer. To calculate normal and abnormal sperm morphology of sperm we used safranin staining and crystal violet.

Testes were fixed in Bouin solution for 24 hours. Then, it was washed with $70 \%$ alcohol repeatedly for approximately 30 minutes so that the yellow color (Bouin solution) is reduced or seems clear. The tissue was dehydrated in graded alcohol solution of $70 \%, 80 \%, 96 \%$ and absolute alcohol for approximately 1 hour to attract water molecules out of the tissue. Furthermore, the tissue was soaked with a solution of benzyl benzoate for 24 hours, then in benzol 2 times for 15 minutes until the tissue was clear or transparent. Infiltration with paraffin was done in several stages. The tissue was soaked in paraffin I for 30 minutes, paraffin II for 60 minutes, and paraffin III for 90 minutes. Infiltration was done in the oven with a temperature of $56^{\circ} \mathrm{C}-58^{\circ} \mathrm{C}$. The next treatment was planting tissues that had been infiltrated in liquid paraffin and placed in paper boxes, and then put in the refrigerator and allowed to clot.

The tissue was cut in 3-5 $\square \mathrm{M}$ thickness using a rotary microtome knife and the resulted slices were placed on a glass slide. Preparations on the slide were heated slowly. Further preparations were soaked in xilol for 5 minutes 2 times. Then the preparations were soaked in a solution of alcohol-rise of high concentrations that was decreased gradually $(100 \%, 90 \%$, $80 \%$ and $70 \%$ ) respectively for 3 minutes. Staining was done with hematoxylin and eosin (HE). Tissues that had been stained were cleared by xilol for 5 minutes to let the tissue look brighter. At the final stage, the testicular tissue on the slide was treated with entellan and covered with a glass lid and then observed. Parameter of the observations of testicular seminiferous tubules including the number of spermatogenic, spermatogonia, spermatocytes and spermatids cells. Statistical analyses used in this study were ANOVA followed by LSD test.

\section{RESULTS}

The results of data analysis showed that no inhibition zone difference between leaf and petiole $(\mathrm{p}=0.000)$. Inhibition zone between bacteria $S$. epidermidis, $S$. aureus and $A$. aerogenes showed no difference $(\mathrm{p}=0.198)$. Inter-dose inhibition zone showed difference $(\mathrm{p}=0.000)$.

Table 1. Average inhibition zone (mm) on S. epidermidis, S. aureus, A. aerogenes bacteria by ethanol extracts of leaf and petiole of Centella asiatica in various doses.

\begin{tabular}{lcccccc}
\hline \multirow{2}{*}{$\begin{array}{c}\text { Doses } \\
(\mathrm{mg} / \mathrm{ml})\end{array}$} & \multicolumn{2}{c}{ S. aureus } & \multicolumn{2}{c}{ S. epidermidis } & \multicolumn{2}{c}{ A. aerogenes } \\
\cline { 2 - 6 } & Leaf & Petiole & Leaf & Petiole & Peaf \\
\hline 500 & 14.67 & 11.33 & 11.67 & 8.00 & 15.67 \\
250 & 12.67 & 8.33 & 10.33 & 6.67 & 12.67 & 7.33 \\
125 & 10.33 & 7.33 & 8.00 & 6.00 & 6.00 & 6.00 \\
62.5 & 8.00 & 6.33 & 6.67 & 6.00 & 6.33 & 31.33 \\
$\mathrm{~K}+$ & 26.67 & 26.33 & 32.67 & 30.00 & 6.00 & 29.00 \\
$\mathrm{~K}-$ & 6.00 & 6.00 & 6.00 & 6.00 & 6.00 & 6.00 \\
\hline
\end{tabular}

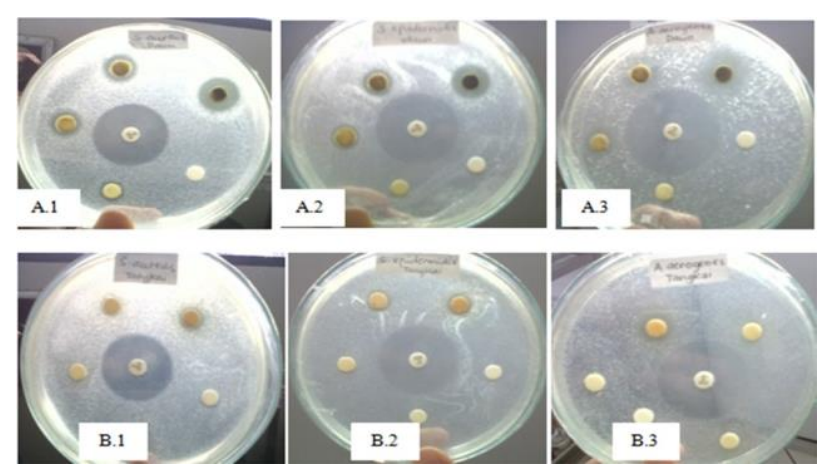

Fig. 1. Diameter $(\mathrm{mm})$ of antimicrobial test inhibition zone in S. aureus, S. epidermidis, and $A$. aerogenes. A: pegagan leaf extract, B: pegagan petiole extract, 1: S. aureus, 2: $S$. epidermidis, 3: A. aerogenes.

S. epidermidis had no inhibition zone difference between extract of leaves and petiole $(\mathrm{p}=0.000)$. Interdose showed no difference $(\mathrm{p}=0.023)$. There was no interaction between dose and extract $(\mathrm{p}=0466)$. Between dose of $500 \mathrm{mg} / \mathrm{ml}$ to $250 \mathrm{mg} / \mathrm{ml}$ there was no difference in inhibition zone. No inhibition zone difference between the dose of $500 \mathrm{mg} / \mathrm{ml}$ to $125 \mathrm{mg} / \mathrm{ml}$ $(\mathrm{p}=0.019)$ and between $500 \mathrm{mg} / \mathrm{ml}$ and $62.5 \mathrm{mg} / \mathrm{ml}$ $(\mathrm{p}=0.005)$. Between dose $250 \mathrm{mg} / \mathrm{ml}$ to $125 \mathrm{mg} / \mathrm{ml}$ there was no difference $(\mathrm{p}=0186)$. Between doses of 250 $\mathrm{mg} / \mathrm{ml}$ with $62.5 \mathrm{mg} / \mathrm{ml}$ no inhibition zone difference 
( $\mathrm{p}=0.063$ ) was found. Similarly, between the dose of $125 \mathrm{mg} / \mathrm{ml}$ and $62.5 \mathrm{mg} / \mathrm{ml}$ did not show inhibition zone difference $(\mathrm{p}=0548)$.

In $S$. aureus, there were differences in inhibition zone and between leaf and petiolde extract Centella asiatica $(p=0.001)$. Between doses also showed inhibitory zone difference $(\mathrm{p}=0.001)$. There was no interaction between the types of extracts and dose $(\mathrm{p}=0701)$. Between doses of $500 \mathrm{mg} / \mathrm{ml}$ to $250 \mathrm{mg} / \mathrm{ml}$ no inhibition zone showed difference $(\mathrm{p}=0.041)$. Between $500 \mathrm{mg} / \mathrm{ml}$ to $125 \mathrm{mg} / \mathrm{ml}$ no inhibition zone difference $(\mathrm{p}=0.002)$ and $500 \mathrm{mg} / \mathrm{ml}$ to $62.5 \mathrm{mg} / \mathrm{ml}$ was also no inhibition zone difference $(p=0.000)$. There was no difference between the dose inhibition zone $250 \mathrm{mg} / \mathrm{ml}$ and $125 \mathrm{mg} / \mathrm{ml}(\mathrm{p}=158)$. Between doses of $250 \mathrm{mg} / \mathrm{ml}$ with $62.5 \mathrm{mg} / \mathrm{ml} \mathrm{no}$ inhibition zone difference $(\mathrm{p}=0.009)$ was found, and there was no inhibition zone difference between the dose $125 \mathrm{mg} / \mathrm{ml}$ and the dose of $62.5 \mathrm{mg} / \mathrm{ml}(\mathrm{p}=0158)$.

In $A$. aerogenes, there was a difference between the inhibition zone and the leaf extract of Centella asiatica petiole $(p=0.000)$. There were differences between the inhibition zone dose $(\mathrm{p}=0.000)$. There was no interaction between the types of extracts and dose $(\mathrm{p}=0.145)$. Between doses of $500 \mathrm{mg} / \mathrm{ml}$ and 250 $\mathrm{mg} / \mathrm{ml}$, and between $125 \mathrm{mg} / \mathrm{ml}$ and $62.5 \mathrm{mg} / \mathrm{ml} \mathrm{no}$ inhibition zone difference $(\mathrm{p}=0.001, \mathrm{p}=0.000, \mathrm{p}=0.000)$ were found. Between doses of $250 \mathrm{mg} / \mathrm{ml}$ and 0.026 $\mathrm{mg} / \mathrm{ml}$ no inhibition zone difference $(\mathrm{p}=0.026)$ was found, and a dose of $250 \mathrm{mg} / \mathrm{ml}$ and $62.5 \mathrm{ml} / \mathrm{ml}$ also showed no inhibition zone difference $(\mathrm{p}=0.003)$. Doses between $126 \mathrm{mg} / \mathrm{ml}$ with $62.5 \mathrm{mg} / \mathrm{ml}$ showed no inhibition zone difference $(\mathrm{p}=0.280)$.

\section{Spermatozoa quality}

The results of this study showed that the extract of Centella asiatica leaf and petiole had significant effect $(\mathrm{p}<0.05)$ to decrease sperm motility in mice. Extracts of Centella asiatica leaf and petiole with a concentration of $125 \mathrm{mg}$ had significant effect $(\mathrm{p}<0.05)$ and extract of Centella asiatica leaf and petiole with a concentration of $150 \mathrm{mg}$ also had significant effect $(\mathrm{p}<0.05)$. It can be concluded that there is a significant effect $(p<0.05)$ between control and treatment. Extract of Centella asiatica leaf and petiole with a concentration of $125 \mathrm{mg}$, and $150 \mathrm{mg}$ showed a decrease in motility of mice significantly compared with $0 \mathrm{mg}$ (control). On the control mean motility was $72 \%$, in group with concentration of $125 \mathrm{mg}$ the mean value was $52 \%$, concentration $150 \mathrm{mg}$ had mean value of $40 \%$ and concentrations of $0 \mathrm{mg}$ had mean motility $70 \%$, concentration of $125 \mathrm{mg}$ had mean value of $38 \%$, and the concentration of $150 \mathrm{mg}$ had mean value of $20 \%$. The results of this study showed that the extract of
Centella asiatica leaf and petiole with a concentration of $125 \mathrm{mg}$ and $150 \mathrm{mg}$ can reduce the concentration of sperm motility of mice and the best in reducing the motility is the extract of Centella asiatica petiole at a concentration of $150 \mathrm{mg}$.

The results of this study showed that the extract of Centella asiatica leaf and petiole had significant effect $(\mathrm{p}<0.05)$ on the loss of viability of spermatozoa of mice. Compared to controls, extracts of Centella asiatica leaf and petiole with a concentration of $125 \mathrm{mg}$ had significant effect $(\mathrm{p}<0.05)$ and extract of Centella asiatica leaf and petiole with a concentration of $150 \mathrm{mg}$ had significant effect $(\mathrm{p}<0.05)$. It can be concluded that there is a significant effect $(p<0.05)$ between control and treatment. Extract of Centella asiatica leaf and petiole with a concentration of $125 \mathrm{mg}$ and $150 \mathrm{mg}$ showed a decrease in viability of spermatozoa of mice significantly compared with $0 \mathrm{mg}$. In the treatment of Centella asiatica leaf extract at a concentration of 125 $\mathrm{mg}$ had an average value of $43 \%$, the concentration of $150 \mathrm{mg}$ had an average value of $26 \%$, at concentrations of $0 \mathrm{mg}$ the average value was $64 \%$. In the treatment of sprigs of pegagan extract at a concentration of $125 \mathrm{mg}$ had an average value of $37 \%$, the concentration of 150 $\mathrm{mg}$ had an average value of $11 \%$, and the average control value was $63 \%$. Extract of Centella asiatica leaf and petiole with a concentration of $125 \mathrm{mg}$ and $150 \mathrm{mg}$ can reduce the concentration of spermatozoa viability of mice and the best in reducing viability is an extract of Centella asiatica petiole at a concentration of $150 \mathrm{mg}$.

The results of this study showed that the extract of Centella asiatica leaf and petiole had significant effect $(\mathrm{p}<0.05)$ in increasing abnormal sperm morphology in mice. Extracts of Centella asiatica leaf and petiole with a concentration of $125 \mathrm{mg}$ a significant effect $(\mathrm{p}<0.05)$ and extract of Centella asiatica leaf and petiole with a concentration of $150 \mathrm{mg}$ a significant effect $(\mathrm{p}<0.05)$. It can be concluded that there is a significant effect $(p<0.05)$ between control and treatment. Extract of Centella asiatica leaf and petiole with a concentration of $125 \mathrm{mg}$ and $150 \mathrm{mg}$ showed an increase in abnormal sperm morphology in mice significantly compared with $0 \mathrm{mg}$. In the treatment of Centella asiatica leaf extract at a concentration of $125 \mathrm{mg}$ with an average value of $66 \%$, the concentration of $150 \mathrm{mg}$ with an average score of $74 \%$ while at the concentration of $0 \mathrm{mg}$ the average value of $38 \%$. In the treatment of sprigs of pegagan extract at a concentration of $125 \mathrm{mg}$ with an average value of $78 \%$, the concentration of $150 \mathrm{mg}$ with an average value of $88 \%$ and at concentrations of $0 \mathrm{mg}$ the average value of $37 \%$.

Extract of Centella asiatica leaf and petiole with a concentration of $125 \mathrm{mg}$ and $150 \mathrm{mg}$ can increase the 
concentration of abnormal sperm morphology in mice and best improve abnormal morphology is petiole pegagan extract at a concentration of $150 \mathrm{mg}$.

The results of this study showed that the extract of Centella asiatica leaf and petiole significant effect $(\mathrm{p}<0.05)$ decrease in the concentration of spermatozoa of mice. Extracts of Centella asiatica leaf and petiole with a concentration of $125 \mathrm{mg}$ a significant effect $(\mathrm{p}<0.05)$ and extract of Centella asiatica leaf and petiole with a concentration of $150 \mathrm{mg}$ a significant effect $(p<0.05)$. It can be concluded that there is a significant effect $(\mathrm{p}<0.05)$ between control and treatment. Extract of Centella asiatica leaf and petiole with a concentration of $125 \mathrm{mg}$ and $150 \mathrm{mg}$ showed a difference significant concentration of spermatozoa of mice compared with controls. In the treatment of Centella asiatica leaf extract at a concentration of 125 $\mathrm{mg}$ with an average value of 56 million $/ \mathrm{ml}$, a concentration of $150 \mathrm{mg}$ with an average value of 43 million/ $\mathrm{ml}$ and the concentration of $0 \mathrm{mg}$ the average value of $68 \mathrm{million} / \mathrm{ml}$. Petiole pegagan extract treatment with a concentration of $125 \mathrm{mg}$ with an average value of $44 \mathrm{million} / \mathrm{ml}$, a concentration of 150 $\mathrm{mg}$ with an average value of $35 \mathrm{million} / \mathrm{ml}$ and the concentration of $0 \mathrm{mg}$ the average value of 65 million/ml.

Extract of Centella asiatica leaf and petiole with a concentration of $125 \mathrm{mg}$ and $150 \mathrm{mg}$ concentration that can lower the concentration of spermatozoa of mice and the best in lowering the concentration of spermatozoa in mice is an extract of the pegagan petiole in concentration of $150 \mathrm{mg}$.

\section{Effect of extracts of Centella asiatica leaf and petiole on testicular spermatogenic cells of mice}

The results of this study showed that the extract of Centella asiatica leaf and petiole significant effect $(\mathrm{p}<0.05)$ decrease in the number of spermatogonia cells of mice. Extracts of Centella asiatica leaf and petiole with a concentration of $125 \mathrm{mg}$ a significant effect $(p<0.05)$ and extract of Centella asiatica leaf and petiole with a concentration of $150 \mathrm{mg}$ a significant effect $(p<0.05)$. It can be concluded that there is a significant effect $(\mathrm{p}<0.05)$ between control and treatment. Extract of Centella asiatica leaf and petiole with a concentration of $125 \mathrm{mg}$ and $150 \mathrm{mg}$ showed a decrease in the number of spermatogonia cells in mice significantly compared with the control. In the treatment of Centella asiatica leaf extract at a concentration of $125 \mathrm{mg}$ with an average value of 126.5 cells, a concentration of $150 \mathrm{mg}$ with an average value of 111 cells and the control average number of 200.5 spermatogonia cells. Petiole pegagan extract treatment at a concentration of $125 \mathrm{mg}$ with an average value of 112.5 cells, a concentration of $150 \mathrm{mg}$ with an average value of 98.5 cells, the control average value of 203.5 cells. Extract of Centella asiatica leaf and petiole with a concentration of $125 \mathrm{mg}$ and $150 \mathrm{mg}$ concentration can decrease the number of spermatogonia cells of mice and the best in reducing the number of spermatogonia cells are extracts of Centella asiatica petiole at a concentration of $150 \mathrm{mg} / \mathrm{kb}$ bw.

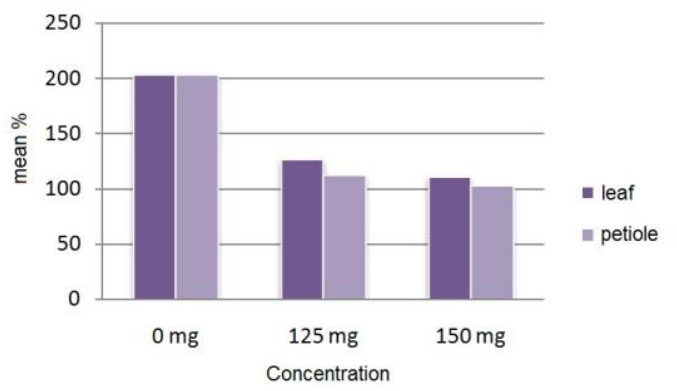

Fig. 2. The decrease in the number of spermatogonia cells with various concentrations.

\section{Spermatocytes}

The results of this study showed that the extract of Centella asiatica leaf and petiole significant effect $(\mathrm{p}<0.05)$ decrease in the number of cells of mice spermatocytes. Extracts of Centella asiatica leaf and petiole with a concentration of $125 \mathrm{mg}$ a significant effect $(\mathrm{p}<0.05)$ and extract of Centella asiatica leaf and petiole with a concentration of $150 \mathrm{mg}$ a significant effect $(p<0.05)$. It can be concluded that there is a significant effect $(\mathrm{p}<0.05)$ between control and treatment. Extract of Centella asiatica leaf and petiole with a concentration of $125 \mathrm{mg}$ and $150 \mathrm{mg}$ showed a decrease in the number of cells spermatocytes significant compared to controls. In the treatment of Centella asiatica leaf extract at a concentration of 125 $\mathrm{mg}$ with an average value of 131 cells, the concentration of $150 \mathrm{mg}$ with an average value of 115 cells and the control average value of 226 cells. Petiole pegagan extract treatment with a concentration of $125 \mathrm{mg}$ with an average value of 121 cells, the concentration of 150 $\mathrm{mg}$ with an average value of 103 cells and the control of the average value of 227 cells. Extract of Centella asiatica leaf and petiole with a concentration of $125 \mathrm{mg}$ and $150 \mathrm{mg}$ concentration can decrease the number of cells of mice spermatocytes and the best in reducing the number of spermatocytes is petiole pegagan extract at a concentration of $150 \mathrm{mg} / \mathrm{kb}$ bw. 


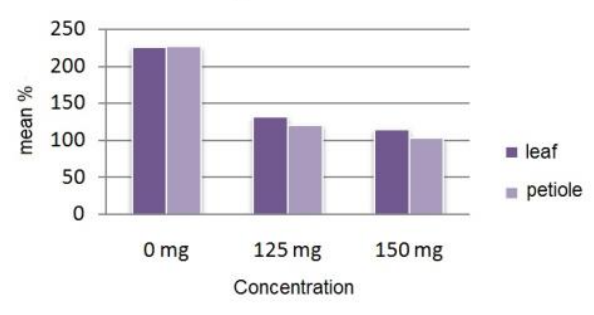

Fig. 3. Effect of extracts of Centella asiatica leaf and petiole of the decrease in the number of cells spermatocytes

\section{Spermatids}

The results of this study showed that the extract of Centella asiatica leaf and petiole significant effect $(p<0.05)$ decrease in the number of spermatid cells of mice. Extracts of Centella asiatica leaf and petiole with a concentration of $125 \mathrm{mg}$ a significant effect $(\mathrm{p}<0.05)$ and extract of Centella asiatica leaf and petiole with a concentration of $150 \mathrm{mg}$ a significant effect $(\mathrm{p}<0.05)$. It can be concluded that there is a significant effect $(\mathrm{p}<0.05)$ between control and treatment. Extract of Centella asiatica leaf and petiole with a concentration of $125 \mathrm{mg}$ and $150 \mathrm{mg}$ showed a significant decrease in the number of spermatids compared with controls. In the treatment of Centella asiatica leaf extract at a concentration of $125 \mathrm{mg}$ with an average value of 127 cells, the concentration of $150 \mathrm{mg}$ with an average value of 113 cells and the control of the average value of 216 cells. Petiole pegagan extract treatment with a concentration of $125 \mathrm{mg}$ with an average value of 111 cells, the concentration of $150 \mathrm{mg}$ with an average value of 100 cells and the control average value of 216 cells. Extract of Centella asiatica leaf and petiole with a concentration of $125 \mathrm{mg}$ and a concentration of $150 \mathrm{mg}$ can reduce the number of spermatid cells of mice and the best in reducing the number of mice spermatids is petiole pegagan extract at a concentration of $150 \mathrm{mg} / \mathrm{kb}$ bw.

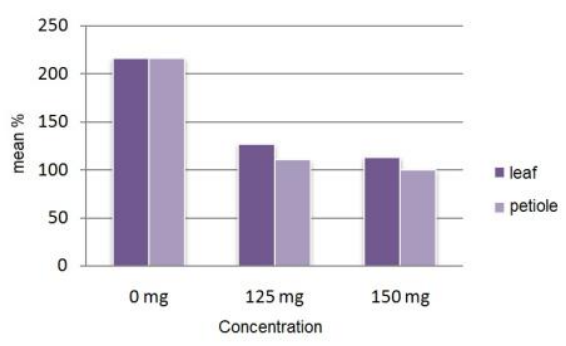

Fig. 4. Effect of extracts of Centella asiatica leaf and petiole of the decrease in the number of spermatid cells.

\section{DISCUSSION}

Antimicrobial activity test was performed at different levels of concentration in order to determine whether the increase in the concentration will increase their antimicrobial activity. Positive control used was ciprofloxacin and the negative control was water. The results showed that the negative control did not leave the zone of inhibition. It was proved that the solvent (negative control) did not affect the antibacterial activity, that activity came from the only test solution (extract of Centella asiatica leaf and petiole at various concentrations) and not of the solvent used.

The results showed that the test solution was an extract of the leaves and petiole of $C$. asiatica leaves had antibacterial activity against $S$. aureus, $S$. epidermidis, and $A$. aerogenes characterized by the presence of obstacles in the area around the paper disk shown in Fig. 1. Its increase raised the concentration of antibacterial activity so that the higher the concentration of $\mathrm{C}$ asiatica leaf extract, the greater the inhibitory zone. While on the petiole of $C$. asiatica extract inhibitory zone resulted was lower than inhibition zone of $C$. asiatica leaf extract. This difference was caused by different compound contained in the leaves and petiole of $C$. asiatica. Test solution $C$. asiatica leaf extract ethanol at a concentration of $500 \mathrm{mg} / \mathrm{mL}$ had the highest antibacterial activity against $S$. aureus, $S$. epidermidis, and $A$. aerogenes. However, use of a positive control $(+)$, the antibiotic ciprofloxacin resulted in the greatest inhibition zone than the test solutions shown in paper disc in the middle (Fig. 1).

The antibacterial activity of $C$. asiatica allegedly caused by the content of phenolic compounds and terpenoids. The mechanism of phenolic compounds as antibacterial at low concentrations is by damaging the cytoplasmic membrane and can cause leakage of the cell nucleus, whereas at high concentrations of phenolic compounds mengkoagulasi cellular proteins. Activity is very effective when the bacteria in the cleavage stage wherein the phospholipid layer around the cell is in a state that is so thin that it can easily damage the phenol content of cells (Volk \& Wheller 1984).

Terpenoids as antibacterial mechanism is reacted with Porin (transmembrane protein) on the outer membrane of the bacterial cell wall, forming a strong bond polymers that cause damage Porin. Damage to Porin which is the entry and exit of the compounds will reduce the permeability of bacterial cell walls that will result in nutritional deficiencies, bacterial cells, so that bacterial growth is inhibited or death (Cowan 1999). 
These results indicate that the presence of the concentration effect of the treatment and the leaf extract of $C$. asiatica petiole on the quality of spermatozoa of mice. In the treatment of leaf and petiole extract of $C$. asiatica with concentrations of $0 \mathrm{mg}, 125 \mathrm{mg}$ and 150 mg showed significant differences. Treatment petiole $C$. asiatica extract at a concentration of $150 \mathrm{mg}$ showed a decrease in the quality of spermatozoa at each observation that sperm motility, sperm viability, sperm concentration and morphology of abnormal spermatozoa.

In this study, extract of $C$. asiatica petiole with a concentration of $150 \mathrm{mg}$ obtained motility $20 \%$. Salman and Adesokan (2007) reported a $52.17 \%$ motility in control mice and $67.50-77.50 \%$ in mice fed the extract Enantia chlorantha (Salman \& Adesokan 2007). Similarly, the report Chauhan et al. (2008) reported a $79.1 \%$ motility in control mice and $54 \%$ in mice fed the extract Aegle Marmelos. Sathiyaraj et al. (2010) reported a $94 \%$ motility in control mice and from 38.7 to $68.6 \%$ in the mice that were given the leaf extract Aegle Marmelos. Reduced motility due to the extract of $C$. asiatica is due to the presence of alkaloids in $C$. asiatica that causes a bottleneck process at the level of the hypothalamus and cause hormonal disturbances resulting in failure of the Leydig cells secrete testosterone. As a result of a decrease in testosterone levels will cause interference with the process of maturation of spermatozoa in the epididymis, especially interference in the process of glycolysis. The glycolysis process will produce energy in the form of Adenosine Tri Phosphate (ATP). ATP is used by spermatozoa as an energy source so that the sperm can remain motile and at the same time to maintain viability. There are two factors that affect sperm motility ie endogenous factors and exogenous factors. Availability of energy resources is very important endogenous factors. The energy source used in sperm motility is Adenosine Tri Phosphate (ATP). On $C$. asiatica leaf extract at a concentration of $16 \%$ decline in sperm motility in mice significantly, as $C$. asiatica also has properties narkotis so in use must be very careful. Award levels excessive dose can cause $C$. asiatica active compounds which act as fertility becomes antifertility.

Tannin compound contained in the leaves and petiole of C. asiatica leaf plasma membrane permeability interfere with the function of spermatozoa that play a role in the transport of food (nutrients) that is essential for cell metabolism. Impaired metabolic activity of sperm cells can cause the death of spermatozoa for cell metabolism will produce lactic acid, and if there are no energy to reshape the lactic acid into energy needed for the activity of sperm motion, it will cause a buildup of lactic acid to lower the $\mathrm{pH}$ of semen or diluent. Lactic acid levels high enough will inhibit the metabolic activity of sperm and also are toxic to spermatozoa that can cause the death of spermatozoa.

Spermatozoa plasma membrane damage caused by leaf and petiole extract of $C$. asiatica excess can damage on the tail or on the head. Eosin color components will enter the cell plasma membrane damage and form a purplish pink color. At the time of mixing sperm and eosin nigrosin, cells that live spermatozoa no or very little to absorb the color, whereas the cells of dead spermatozoa will absorb color due to increased cell wall permeability.

Plasma membrane integrity is a prerequisite for the survival of spermatozoa. If the plasma membrane is disturbed or damaged it will cause anisosmotik condition that causes the leakage of intracellular ATP overhaul will affect them thus affecting motility. Plasma membrane integrity of spermatozoa could be damaged if the presence of toxic substances that are both derived from the spermatozoa that have died or are derived from substances contained of a diluent which has undergone oxidation due to storage can lead to high levels of free radicals. When the plasma membrane spematozoa already damaged, then the spermatozoa metabolism will be disturbed so that the sperm begin to lose motility and sperm for fertilization ability due to the release of cellular components and inactivation of proteins are important enzymes in the acrosome. This incident resulted in the death of spermatozoa which impact on the viability of spermatozoa.

In this study, the results obtained control mice sperm concentration of $68.25 \mathrm{million} / \mathrm{ml}$ and decreased to its lowest sperm concentration at treatment petiole pegagan extract at a concentration of $150 \mathrm{mg} / \mathrm{Kg}$ bw ie 35.25 million/ml. Salman and Adesokan (2007) reported concentrations of some 55.83 million sperm cells $/ \mathrm{ml}$ in the control mice and from 56.67 to 63.00 million cells $/ \mathrm{ml}$ in rats fed the extract Enantia chlorantha (Salman \& Adesokan 2007). Chauhan et al. (2008) reported concentrations of 56.6 million cells $/ \mathrm{ml}$ in the control mice and 40.2 cells $/ \mathrm{ml}$ in rats fed the extract Aegle Marmelos. Kachhawa et al. (2010) reported concentrations of 73.83 million sperm cells $/ \mathrm{ml}$ in the control mice, and 18.55 million cells $/ \mathrm{ml}$ in mice treated Momordica dioica. The concentration of spermatozoa is the reproducibility of male animals which can be determined by the quality and quantity of cement produced. High cement production is expressed with high semen volume and sperm concentration is also high. The content of steroid compounds in leaf and petiole of $C$. asiatica lead to increased testosterone causes negative feedback to the pituitary is not releasing FSH and LH, causing dysfunction in Leydig cells that 
lead to low sperm concentration. The decline in production will cause interference on epididymal function in the process of maturation of spermatozoa.

Morphology of spermatozoa in the present study found abnormalities in primary and secondary abnormalities. The sperm abnormalities due to steroid compounds found in the leaves and petiole of $C$. asiatica that can disrupt the process of spermatogenesis. Primary abnormality that occurs due to abnormalities of spermatogenesis in the seminiferous tubules and secondary abnormalities that occur after spermatozoa leave the seminiferous tubules and during its passage through the epididymis. Some forms of primary abnormality among others macrocephalic or head is too big that it could be because they contain diploid chromosome, or a microcephalic head is too small, wide head (round), double head, the middle folded, curled tails, broken or split. Many factors can cause sperm abnormality that occurs during the process of spermatozoa. The abnormality may be caused by impaired ATPase, high body temperature and impaired function of the epididymis, can cause abnormalities in spermatozoa.

Based on the results of this study also found that $C$. asiatica can decrease spermatogenic cells of mice. A decrease in spermatogenesis in mice showed a decrease in spermatogenic cell population that occurs in all of the doses administered. This decline increased with increasing doses of the extract of leaves and petiole $C$. asiatica given to mice (Mus musculus) as the experimental animals. In the treatment of leaf and petiole of $C$. asiatica with compared to the control, the concentration of $125 \mathrm{mg} / \mathrm{kg}$ bw and $150 \mathrm{mg} / \mathrm{kg} \mathrm{bw}$ showed a significant difference. Treatment of $C$. asiatica petiole with a concentration of $150 \mathrm{mg} / \mathrm{kg}$ bw showed a decrease in spermatogenesis were higher in the observation cell spermatogonia, spermatocytes and spermatids.

In this research note that the extract of leaf and petiole of $C$. asiatica at a dose of $150 \mathrm{mg} / \mathrm{kg}$ bw was able to reduce the number of spermatogonia cells. The increase in premature sperm cells is associated with stimulation of mitotic germ cells with inhibition of meiotic division that led to discontinuation of the maturation of sperm cells in several stages of development. The decline in the number of spermatogonial cells may be caused by the presence of the active substance tannin alleged role in reducing the number of spermatogonia cells. Compounds antifertility the herb works in 2 ways, namely through a cytotoxic effect and through hormonal effects that inhibit the metabolism rate spermiogenesis cells by interfering with the balance of the hormone system. Allegedly tannins in the leaves and petiole of $C$. asiatica worked as compound antifertility through hormonal effects. Tannins can be used as feedstock for the synthesis of steroid hormones. Steroids are the basic structure of the hormone testosterone. Mechanism of action of the active compound in through steroid biosynthesis especially estosteron will produce materials similar in structure to testosterone. Testosterone has the effect of negative feedback on the anterior pituitary gland, as reinforcement in the anterior pituitary feedback to the hypothalamus. This feedback is specifically thought to inhibit the synthesis and secretion of $\mathrm{LH}$ and will lower the secretion of testosterone. Testosterone can cause this kind of feedback is testosterone-free.

Free testosterone can enter into the target organ (Sertoli cells) passively through the process of diffusion. The free testosterone which is more active more products is dehyidrotestosterone. Changes testosterone into dehydrotestosteron catalyzed by the enzyme 5- $\square$ reductase. Dehydrotestosterone this will cause the release of a particular protein (Hsp 90) of androgen receptors thus allowing DHT binds to the androgen receptor is present in Sertoli cell cytoplasm. Dehidrotestosteron-receptor complexes will enter into the cell nucleus and interact with specific sequences of DNA of the Sertoli cells. This attachment will induce the synthesis of mRNA. DHT-androgen receptor complex-DNA together with RNA polymerase and the protein basal transcription will initiate the process of protein synthesis, which in turn will form the androgen dependent protein. Proteins are synthesized in Sertoli cells needed for the division/meiosis of spermatogonia. Spermatogonia formed will undergo a process of development to become spermatocytes, spermatids and spermatozoa.

Disruption to spermatogenesis related to the active ingredient contained in pegagan extract, such as flavonoids. Bhargava (1989) reported that treatment with flavonoids causing damage to the final stages of spermatogenesis. Zha et al. (2008) suggested that the mechanism of action of drugs on male antifertility associated with apoptosis of spermatogenic cells. In addition, a decrease in the number of late spermatids can be caused by a decrease in testosterone levels. Sewani-Rusike and Gundidza (2011) reported that a decrease in spermatogenesis associated with testosterone deficiency. Effects can antiandrogenik through the function of the hypothalamus and anterior hipophisa or directly to the testes. Gonadotropin hormones namely $\mathrm{LH}$ and FSH are regulators of spermatogenesis. LH increases cholesterol transport into mitochondria from the cytosol in Leydig cells (Barlow et al 2003). FSH and testosterone in a synergistic role in the maturation of germ cells (Haywood et al 2003). 
Testosterone itself can induce maturation of germ cells independently of FSH activity (Spaliviero et al 2004).

A decrease in the number of cells spermatocytes also influenced the presence of active substances triterpenoids glikiosida. Triterpenoids linked with the steroid biogenesis by signing in steroid biosynthesis pathway mainly in the production of testosterone resulting in a material that is similar to testosterone. Triterpenoid glycosides in $C$. asiatica contained progesterone (P4) and estradiol (E2), which can cause impaired secretion of FSH and LH. FSH barriers will cause interference with the process of mitosis and proliferation. FSH is indispensable in the proliferation of the number of spermatogonial cells. Triterpenoids also able memurunkan number of spermatocytes by way of negative feedback on the hypothalamus and anterior pituitary $\mathrm{GnRH}$ and thus causing Gonadotropin Hormone (FSH and LH) inhibited.

The hypothalamus secretes GnRH (gonadotrophin releasing hormone) which stimulates the anterior pituitary gland to secrete folicle Stimulating Hormone (FSH), Luteinizing Hormone (LH). Both these hormones play a major role regulate male sexual function. FSH is carried through the bloodstream to the testicles and started the process of spermatogenesis proliferation. LH hormone released by the pituitary binds to the receptor in the cells of the testes interstial. After the bond between LH and its receptor will form the second messenger cAMP form. The formation of cAMP activates protein kinase that will affect the cell nucleus to the gene that regulates the biosynthesis of testosterone become active and will begin pensintesisan protein. Testosterone biosynthesis involves a variety of substances, enzymes, and other steroid hormones. With the presence of triterpenoid glycosides activation of protein kinase become blocked, causing testosterone and spermatogenesis process is inhibited.

Spermatid cell count decline was caused by the presence of alkaloids and flavonoids which have roles suppress the secretion of reproductive hormones, namely testosterone so disturbed spermatogenesis process. High or low testosterone levels (below the normal threshold) results in a negative feedback on the hypothalamus and result in impaired spermatogenesis process, if the levels of testosterone ormal will bully the testes to make the process of spermatogenesis.

Testosterone is the main hormone produced by the Leydig cells as a result of stimulation of Luteinizing Hormone (LH) from the anterior pituitary, which is needed in spermatogenesis. In the seminiferous tubules, testosterone serves to control spermatogenesis in meiosis and spermiogenesis. Declining levels of testosterone would interfere with spermatogenesis. Phytoestrogens are known to inhibit 17- $\square$ hydroxysteroidoxyreductase, an enzyme needed in androstenodion conversion to testosterone, so the deficiency of this enzyme, resulting in a decrease in testosterone levels. Phytoestrogens also have the ability to effect, or the effect of estrogen and anti-estrogen for structural similarity with estradiol hormone found in humans. Phytoestrogens raises anti-estrogenic effect if it is in an environment with high estrogen concentrations, and otherwise rises if estrogenic effects in the environment with lower estrogen concentrations. The estrogenic effects that subsequently arise in male mice is due to low concentrations of estrogen. The emergence of this estrogenic effect may result in decreased androgen. The decline in androgen, causing a decrease in testosterone levels as the largest androgens produced by testes.

The active compounds contained in extracts of Centella asiatica possibility of causing damage to the Sertoli cells, which are directly involved in the production of spermatozoa and spermatogenesis continuity, so that damage to these cells will lead to termination of the spermatogenic process. Farnsworth and Waller (1982) reported that a large number of plants that have the effect spermicide or immobilizing sperm contain saponins, flavonoids and phenols (Farnsworth \& Waller 1982). Similarly Ogbuewu et al. (2011) reported that spermisid effects of the plant is the result of phytochemic compound (Ogbuewu et al 2011).

\section{REFERENCES}

Barlow NJ, Philips SL, Wallace DG et al (2003). Quantitative changes in gene expression in the fetal rat testis following exposure to di (n-butyl) phthalate. Toxicol Sci 73, 431-441.

Bhargava SK (1989). Antiandrogenic effects of a flavonoid-rich fraction of Vitex negundo seeds: a histological and biochemical study in dogs. J Ethnofarmacol 27, 327-339.

Chauhan A, Agarwal M, Kushwaha S, Mutreja A (2008). Antifertility studies of Aegle marmelos Corr., an Indian medicinal plant on male albino rats. Egypt $\mathbf{J}$ Biol 10, 28-35.

Cowan M (1999). Plant product as antimicrobial agent. Clinical Microbiology Reviews 12, 564-582.

Farnsworth NR, Waller DP (1982). Current status of plant products reported to inhibit sperm. In: Zatuchni GI (ed). Research frontiers in fertility regulation, Evanston, Northwestern University, p 1-16.

Govindan D, Sambandan TG, Govindan M et al (2007). A bioactive polyacetylene compound isolated from Cantella asiatica. Planta Medica 73:597-599. 
Haywood M, Spaliviero J, Jimenez M, (2003). Sertoli and germ cell development in hypogonadal mice expressing transgenic FSH alone or incombination with testosterone. Endocrinology 144, 509-517.

Kachhawa JBS, Sharma A, Gupta RS, Sharma KK (2010). Evaluation of reversible contraceptive efficacy of methanol extract of momordica dioica root in male albino rats. J Repro Infertil 1, 71-78.

Ogbuewu IP, Unamba-Oparah IC, Odoemenam VU et al (2011). The potentiality of medicinal plants as the source of new contraceptive principles in males. North Am J Med Sci. 3, 255-263.

Pan J, Kai G, Yuan C et al (2007). Separation and determination of madecassic acid in extracts of Cantella asiatica using high performance liquid chromatography with $\beta$-cuclodextrin as mobile phase additive. Chinese Journal of Cromatography 25, 316318.

Rumalla CS, Ali Z, Weerasooriya AD et al (2010). Two new triterpene glycosides from Cantellaasiatica. Planta Medica 76, 1018-1021.

Salman TM, Adesokan AA (2007). Sperm quality of male rats treated with aqueous extract of Enantia chlorantha stem bark. Afr J Biotechnol. 7, 865-867.

Sathiyaraj K, Sivaraj A, Madhumitha G et al (2010). Antifertility effect of aqueous leaf extract of Aegle marmelos on male albino rats. Int J Curr Pharmaceu Res. 2, 26-29.
Sewani-Rusike CR, Gundidza M (2011). Antifertility effects of oldenlandia affinis in male rats-a preliminary study. Afr J Tradit Compl Altern Med $8,: 425-428$.

Sondhi NR, Bhardwaj S, Kaur M et al (2010). Inhibition of H2O2-induced DNA damage in single cell gel electrophoresis assay (comet assay) by castasterone isolated from leaves of Cantella asiatica. Health 2, 595-602.

Spaliviero JA, Jimenez M, Allan CM (2004). Handelsman DJ. LH receptor mediated effects on inhibition of spermatogenesis in gonadal deficiency mice are replicated by testosterone. Biol Reprod. 70, 32-38.

Subban RA, Veerakumar R, Manimaran KM et al (2008). Two new flavonoid from Cantella asiatica (Linn.). Journal of Natural Medicines 62:369-373.

Suntornsuk L, Anurukvorakun O (2005). Precision improvement fot the analysis of flovanoids in selected Thai plants by capillary zone electrophoresis. Electrophoresis 26, 648-660.

Volk and Wheller (1984). Mikrobiologi Dasar. Translated by Adisoemarto S. Jakarta, Erlangga.

Wang XS, Duan JY, Fang JN (2004). Structural features of a olygosaccharide from Cantella asiatica. Chinese Chemical Letters 15, 187-190.

Zha SW, Sha J, Huang YF (2008). Male antifertility drugs and cell apoptosis. Nat J Andro 14, 75-78. 